\title{
Chapter 1 \\ International Perspectives on the Pedagogies of Educational Transitions
}

\author{
Nadine Ballam, Bob Perry and Anders Garpelin
}

There has been a great deal written recently about children starting school, particularly primary school. All of the stakeholders in these transitions to school have been considered, along with matters of readiness - for child, family, educators, schools, and communities; adjustment and adaptation; continuity and change in curricula and learning; and the opportunities, aspirations, expectations and entitlements encompassed in the transformation of roles involved. As the children move from their prior-to-school experiences - preschool, child care, home, other out-of-home care - to school, they experience many changes. One of these is often a change from a primarily play-based pedagogical approach in the prior-to-school setting to perhaps a more structured, even formal pedagogy in school. But what about the pedagogies of the transitions themselves? Children do not stop learning and teachers do not stop teaching as children are in the process of transition to school. There are pedagogies of transition employed. This book explores these pedagogies through the work of an international alliance of transitions to school researchers from five countries - Iceland, Scotland and Sweden (European) and Australia and New Zealand (Antipodean). This alliance is named POET - Pedagogies of Educational Transitions.

\subsection{Introduction}

The transition to school has increasingly become a focus of attention for researchers, policymakers, practitioners, parents and others with an interest in children's lives. This focus has developed, in part, out of a growing recognition of the importance of early experiences and their influence on positive outcomes in later years (Australian Institute of Health and Welfare 2015; Dockett and Perry 2007; Dockett et al. 2014; Organisation for Economic Co-operation and Development [OECD] 2012; Perry et al. 2015; United Nations Children's Fund [UNICEF] 2012).

Increased interest in any field tends to stimulate provocative discussion and debate and the area of educational transitions has not escaped this. Transition itself is a contested phenomenon that has no universally accepted definition (Dockett et al. 2014); what is considered a successful transition might well differ between stakeholders in diverse contexts and cultures, and across time. However, there is general agreement that a child's sense of belonging in the new setting marks an optimal transition to school (Brooker 2008; Bulkeley and Fabian 2006; Dockett and Perry 2004). While there is less agreement about how a sense of belonging or a positive transition might be achieved or measured, the discussion and debate exposes the many ways in which it might be conceptualised.

The transition to school is experienced and understood in varied ways in different contexts, many of which are captured in this book. Many years of transitions research have presented ideas including readiness (Dockett and Perry 2009; Graue 2006; Graue and Reineke 2014), continuity (Brooker 2008; Einarsdóttir 2007), adjustment (Margetts 2014) and adaptation (Woodhead and Brooker 2008). All of these ideas are, and should be, continually questioned, challenged, teased out and reshaped into further notions about children's transitions to school.

\subsection{Transition to School Theories}

While "[M]ost researchers see theory as an important aspect of educational research" (Einarsdóttir 2014 , p. 21), others point out that there are dangers in adhering too closely to a particular theory. While not always explicitly stated, all of the chapters in this book that report on particular research studies are based in a theory or, perhaps, some combination of theories. The major theories used are identified briefly in this section. 
Just as there are many ways for children and other stakeholders to experience transition to school, there are many different theoretical underpinnings utilised in transition to school research (Dockett et al. 2014). Much of the work in this book utilises the work of Bronfenbrenner, either through his early conceptualisations of ecological transitions (Bronfenbrenner 1979; Dunlop 2014) or his later bioecological theory, particularly the Process-Person-Context-Time (PPCT) model (Bronfenbrenner and Morris 2006) with its emphasis on proximal processes. Dockett et al. (2014, p. 4) note that:

The PPCT model provides a great deal of flexibility in researching transition to school. When applied in full, it prompts attention to the relationships and interactions associated with starting school, the characteristics and resources each individual (be they a child, family member, or educator) brings with them to the transition, recognition of the various systems or contexts in which children and families are located, as well as attention to specific events, patterns of interactions and historical context. It provides potential to explore issues of continuity and change, in terms of the individuals, the nature of experiences and interactions they have, the people with whom they interact and the contexts in which they are located. It also recognises that social and cultural contexts are dynamic, affected by processes of continuity and change.

Building on Bronfenbrenner's theories and using other conceptualisations of transition to school is a feature of the book. For example, the conceptualisation of transitions to school using van Gennep's (1960) 'rites of passage' invokes a three phase vision of transitions in terms of preliminal, liminal, and postliminal times and spaces, and the ambiguity that children and other stakeholders may find as they move through these phases. Notions of 'bridges' (Garpelin 2014; Huser et al. 2015), 'chasms' (Garpelin 2014) or 'borderlands' (Giroux 2005; Peters 2014) are all invoked from such a conceptualisation.

Elder's (1996) 'life course' theory, which emphasises human agency over time, can be utilised in conjunction with bioecological theory to place transition to school as part of a person's life history. This is particularly useful in studies that reflect on past transitions to school and in the development of the notion of 'transitions capital' (Dunlop 2014).

Many of the chapters in the book utilise a critical theoretical stance. Such a stance goes beyond the nested systems of ecological theory or the location of the child at the centre of the transition process to consider the social, economic and political contexts involved. Critical theory is particularly important in the chapters considering issues of diversity in children's transition to school. In particular, when researching the starting school experiences of Indigenous children, families, and communities, both Kaupapa Māori research approaches (Pihama 2010) and Critical Indigenous Research Methodology (CIRM) (Brayboy et al. 2011) are brought to bear as culturally appropriate, respectful protocols that are "rooted in Indigenous knowledge systems, [are] anticolonial and [are] distinctly focused on the needs of communities" (Brayboy et al. 2011, p. 423). The construct of 'cultural interface' (Nakata 2007) also allows a critical, anticolonial theoretical stance on researching children's transition to school that has not been used in previous transition to school research.

Underlying each study reported in this book, there is (or are) one or more theories about researching children's start to school. Some of the major ones have been outlined but others are also used. These are not always explicitly stated nor explicitly applied throughout the studies but are there guiding the studies and their reporting. Einarsdóttir (2014) explains her process, which has inspired many of the researchers who have reported their work in this book:

Theories are an important part of educational research. I use theory as a tool to develop research questions and to shed light on the generated data. Theory helps me see what is visible in a new light, notice novel things, and reveal new understandings. I also use it to help me understand the reality that I am investigating and explain what I see, why I see it, and what it means. However, I usually do not explicitly start a study with a specific theory; rather, I let the data help me decide which theory to use. I find that determining the theory beforehand could become restricting and could limit what I see, and how I analyze and interpret what I see. On the other hand, I am well aware that my implicit theories and beliefs about children, childhood, and education influence my decisions about what to study, the design of the study, what I see, and how I interpret it. In that way theory is also a foundation for the study design. (pp. 28-29)

\subsection{Pedagogies of Educational Transitions}

This book is about pedagogies of educational transitions, particularly those developed and used as children start school. Transition to school provides opportunities for the study of pedagogies as it incorporates spaces and times where (often) different approaches to curriculum, teaching and learning are invoked. It is critical that there is an understanding of the meaning that the editors and authors of this book are using for 'pedagogies of educational transition'. This is a new term that must be defined 
in a way that is meaningful, but flexible enough to allow its application in many different national, personal, political and cultural contexts.

The working definition of pedagogy for the longitudinal studies undertaken by Sylva, Siraj-

Blatchford and their colleagues is:

... that set of instructional techniques and strategies which enable learning to take place and provide opportunities for the acquisition of knowledge, skills, attitudes and dispositions within a particular social and material context. It refers to the interactive process between teacher and learner and to the learning environment. (Siraj-Blatchford et al. 2002, p. 10)

In 2005, Learning and Teaching Scotland defined 'pedagogy' in the following way:

Pedagogy is about learning, teaching and development, influenced by the cultural, social and political values and principles we have for children in Scotland, and underpinned by a strong theoretical and practical base. (p. 9)

The equivalent statement in the Australian Early Years Learning Framework defines 'pedagogy' as:

... early childhood educators' professional practice, especially those aspects that involve building and nurturing relationships, curriculum decision-making, teaching and learning. (Department of Education, Employment and Workplace Relations 2009, p. 9)

These definitions have influenced the authors in this book as they consider pedagogies in educational transitions.

In 2011, the Educational Transitions and Change (ETC) Research Group published the Transition to School: Position Statement following intensive work from transitions to school researchers from many countries (Dockett and Perry 2014b). This statement characterised transition to school as a time of opportunities, aspirations, expectations and entitlements for all involved. These constructs, linked to previous definitions of pedagogies in early childhood education have led Davies (2014) to define 'pedagogies of educational transition' as:

... the interactive processes and strategies that enable the development of opportunities, aspirations, expectations and entitlements for children, families, educators, communities and educational systems around transition to school, together with the theories, beliefs, policies and controversies that shape them. (p. 25)

It is this definition which implicitly underlies the chapters in this book and which is explicitly developed in Chapter 12.

\subsection{POET International Alliance}

This book is the first consolidated publication arising from the Pedagogies of Educational Transitions (POET) international alliance. It is planned to be the first of many such publications.

The POET international alliance was originally developed by six experienced transition-to-school researchers from the five countries involved: Sue Dockett (Charles Sturt University, Australia); AlineWendy Dunlop (University of Strathclyde, Scotland); Jóhanna Einarsdóttir (University of Iceland, Iceland); Anders Garpelin (Mälardalen University, Sweden); Bob Perry (Charles Sturt University, Australia); and Sally Peters (University of Waikato, New Zealand). Each of these researchers had many years of experience in the development and implementation of quality research in the area of educational transitions and had published widely. While they had not worked together extensively, they had met at a number of conferences such as those of the American Education Research Association (AERA), European Educational Research Association (EERA) and the European Early Childhood Education Research Association (EECERA), including some joint presentations. All were members of the EECERA Special Interest Group, which had been initially co-chaired by Aline-Wendy Dunlop and, since 2011, has been co-chaired by Sue Dockett. Over the last four years, between 2012 and 2016, these researchers along with a total of more than 100 of their colleagues have engaged in a series of biannual exchanges focused on educational transitions, as part of the European Union Marie Curie International Research Staff Exchange Scheme (IRSES). Further details about the genesis, vision, purpose, structure, activities and funding of POET is provided in an appendix to this book. For the time being, however, we focus on the product. 


\subsection{Structure of the Book}

This book contains five sections, each of which reflects lenses through which the transition to school is conceptualised by current international scholars.

\subsubsection{Diversity and Inclusion in Transition to School}

Diversity and inclusion have increasingly become central to educational policy documents around the globe (OECD 2012; UNICEF 2012; Woodhead and Moss 2007), with an emphasis on groups of children who might be perceived to be at a disadvantage in many areas, including in their schooling. These groups are consistently reported to include children with learning difficulties or disabilities, children from low socio-economic households, children from ethnic minorities and increasingly, refugee children. Part I of the book considers the transition to school for children from many of these groups.

Hellblom-Thibblin and Marwick (Chapter 2) open this section with an overview of ideas about diversity and educational transitions, written with the background of the authors' own countries Sweden and Scotland. The authors contend that the way diversity is conceptualised and inclusion is enacted directly influences the way children are perceived and received in educational contexts.

The following three chapters in Part I examine specific groups of children and their transitions into the school setting. Mitchell et al. (Chapter 3) outline a study undertaken with refugee families in New Zealand, exploring the transition from home into an early childhood setting. Their study indicated that an important transitional element for these families was not only bridging oral language but also aspirations, values and beliefs. The findings provide valuable considerations for families, educators and other professionals involved in the transition of refugee children from early childhood to school settings.

In their move from preschool to primary school, many Swedish children transition through preschool class, providing an important context for the study reported in Chapter 4. In this chapter, Hellblom-Thibblin et al. use an ecological model to consider the obstacles and challenges associated with these transitions for children who have learning difficulties and disabilities.

Wilder and Lillvist (Chapter 5) also explore educational transitions for young children with special learning needs, presenting preliminary findings from an ongoing study undertaken with children transitioning from preschool to compulsory school for students with intellectual disabilities (CSSID). Aspects such as the transfer of knowledge, teacher attitudes and collaboration between home and school provide insights into the continuity of learning over the transition period for these children.

\subsubsection{Transition to School for Indigenous Children}

The theme of diversity and inclusion continues in Part II of this book, with a special focus on Indigenous children from Aotearoa New Zealand and Australia. In Chapter 6, Hohepa and McIntosh, both Indigenous researchers from Aotearoa New Zealand and Australia respectively, provide an overview chapter that considers research related to the transition to school for Indigenous children in these two countries, Indigenous research approaches, and the implications of these for educational transitions. The chapter adopts a critical post-colonial lens and demonstrates the importance of critical Indigenous research paradigms.

Hohepa and Paki (Chapter 7) follow with an outline of the history of educational provisions for Māori, the Indigenous people of Aotearoa New Zealand. With an emphasis on the regeneration of language, cultural identity and values that are important to Māori communities, these authors outline elements that underpin effective transitions for Māori children into both Māori immersion and mainstream educational settings.

In the final chapter of Part II (Chapter 8), Dealtry et al. report on a study that draws from a larger multidisciplinary research project with an Aboriginal community in Australia. The smaller study reported in this chapter takes a social justice view of the way educators conceptualise and engage with Aboriginal children as they transition to school. The authors offer particular insights into the complexities of notions of diversity. 


\subsubsection{Continuity and Change as Children Start School}

Part III of the book explores the notion of continuity, which has been widely debated in terms of its role in the transition to school (Dockett et al. 2014; Dunlop and Fabian 2002). The chapters in this section present continuity and change as being not only about academic learning but also about relationships, pedagogy and practice, curriculum, resources, and support (Dockett and Perry 2014a).

Dockett and Einarsdóttir open Part III of this book with a comprehensive overview of research and literature related to continuity and change in educational transitions (Chapter 9). There is critical coverage of the debate around the role of these elements in transitions and Dockett and Einarsdóttir urge readers to consider the opportunities that both continuity and change offer children, families and other stakeholders in the transition to school.

The other four chapters in this section each explore different aspects of continuity and change in educational transitions. Garðarsdóttir and Ólafsdóttir (Chapter 10) report on a study undertaken collaboratively with preschool educators in Iceland. This study focused on the implementation of the curriculum learning area, 'Health and Well-being', in the early childhood context and the way this might then be experienced by children when they transition into primary school settings. In Chapter 11, also based on studies in Iceland, Karlsdóttir and Perry explore the role of play in the pedagogies of educational transitions as children move from preschool to primary school. In particular, these authors consider how children and their teachers can use children's participation repertoires (Carr, 2001) to promote continuity across the transition.

Curriculum and pedagogy provide the focus for Chapter 12, in which Dockett et al. provide a preliminary analysis of the influence of two recent curriculum reforms in the Australian context. In this analysis, the continuity between curriculum documents for early childhood and school sectors is investigated and the authors consider what this might mean for children's transitions between these settings. The final chapter of Part III (Chapter 13) describes a study undertaken in Iceland, which focused on mathematics and play. Garðarsdóttir et al. worked with educators in both a preschool and a primary school to establish pedagogical continuity in mathematics learning across the two settings. This study highlights some of the common and differing perspectives between educators in these settings and the way these influence children's transition experiences.

\subsubsection{Borderlands, Bridges and Rites of Passage}

Transition to school can be explored through the lens of 'crossing borders' (Brooker 2002; Garpelin 2011; Hartley et al. 2012; Peters 2004, 2014). Dockett et al. (2014) reflected that conceptualising the transition to school in this way raises a number of questions about both the border and the borderlands surrounding it, and all those involved in ensuring safe passage for children through transition spaces. This section also draws on the work of van Gennep (1960), who conceptualised the transition to school as a 'rite of passage'.

In the opening chapter for Part IV (Chapter 14), Peters and Sandberg consider ways in which educational transitions have been theorised and conceptualised. These authors outline several studies that have used the concepts of traversing borders, crossing bridges, and rites of passage to explore points of transition in various ways.

In Chapter 15, Sandberg et al. discuss the implications of pedagogy and practice in Sweden across preschool, preschool class and primary school for children's learning journeys. The authors draw on studies they have undertaken that focus on the activities in each of the three settings, as well as some of the associated challenges for children in their transition through the three school forms in their early years.

\subsubsection{Into the Future}

Part V explores future directions in educational transitions research. Dunlop (Chapter 16) introduces the idea of transitions as a tool for change, a perspective generated by the Scottish POET team through their ongoing projects. From this perspective, there is less focus on problematising transitions and more 
on demonstrating that successful transitions can result in positive, transformative changes for all stakeholders.

In Chapter 17, the POET project team leaders from each participating country bring the book to a close with a synthesis of themes emanating throughout the book and suggestions for future research in the field of educational transitions. Dockett et al. emphasise that commonalities from research undertaken in each of the five participating POET alliance countries have the potential to contribute significantly to addressing some of the challenges faced in this area.

\subsection{Using this Book}

The POET project has been one where some members have been able to sustain their involvement throughout the project's duration from 2012 to 2016, while others have visited the activities intermittently, as their circumstances allowed. In every case, each POET member has received some benefit from his or her involvement and engagement. To a large extent, readers of this book, which has emanated from the POET activities and underlying country projects, will be able to choose their level of engagement with the book - some will want to read it from cover to cover, while some will want to visit only certain sections or even single chapters. The editors and the authors have tried to ensure that these various levels of engagement are possible.

The editors believe that this book reflects the vision of the POET international alliance through collaborative writing and the wide scope of projects reported. While much of the book addresses educational transitions to primary school, there are considerations around educational transitions that are much broader than this. Hence, while the various chapters do consider important challenges and issues around transition to school, we hope that the agenda can be broadened substantially using the information in the book as a base.

From the individual projects reported in this book, the editors and authors know that their work is well received by others. This book is written for educational transitions researchers, policymakers, higher degree candidates and practitioners, in the hope that it will assist them in their own work, as we all strive for optimal educational transitions for all children, families, educators and other stakeholders.

As Dockett et al. highlight in Chapter 17, there is still much to be done and many new and interesting pathways to be explored through further quality research. Some of that will undoubtedly occur as a direct result of the POET international alliance and will be undertaken by POET members. Much of this will be reported in other planned publications from the POET group. However, it is the editors and authors' hope that this book will inspire researchers, policymakers and practitioners beyond POET to choose their pathways and to assist all stakeholders in educational transitions to reach their optima.

\section{Acknowledgements}

In order for the POET project to function, funding was required. A large part of this funding, allowing exchange of European POET members, came from the Marie Curie International Research Staff Exchange Scheme FP7, conducted by the European Commission. The funding for the New Zealand members, through the New Zealand-EU International Research Staff Exchange Scheme, was supported by government funding and administered by the Royal Society of New Zealand. A small amount of the funding for the Australian contingent was provided by Charles Sturt University. All of these funding sources are gratefully acknowledged. Individual research project funding from many sources will be acknowledged in the relevant chapters.

The editors would also like to acknowledge all of their POET colleagues who not only wrote chapters for this book but also helped in the reviewing of the manuscript and generally provided encouragement during the difficult times that inevitably occur in the editing of such a complex book. Thank you for providing the opportunity for us to bring your work together and showcase what we have achieved in POET over the last four years.

A special vote of gratitude goes to Professor Sue Dockett who not only led the writing of a number of the chapters in the book but also provided great support to the editors through her reviewing of all the chapters and provision of advice on structure and approach. 


\section{Collaboration Between Editors}

A secret to sustainable and effective research activity in any field of work is for those more experienced to have a willingness to nurture those less experienced and then to put this into practice. At the heart of the POET alliance is the notion of mentoring less experienced colleagues. This notion is tangibly implemented within the context of POET through the promotion of collaboration between researchers at varying stages in their careers, and consequently transmission of skills, knowledge and understanding.

In a number of ways, the editorship of this book exemplifies the underlying intention of the POET alliance to be a platform for mentoring. The first editor of this book, Nadine Ballam, is an early-career researcher. The willingness of more experienced researchers, Bob Perry and Anders Garpelin, to take on mentoring roles in this editorial team reflects, in action, precisely what was conceived in the initial planning of the POET collaboration. The existing partnership between these two experienced researchers has provided a safe, dependable foundation upon which someone less experienced can learn. This is significant, and exemplifies that it is not only theoretical knowledge and understandings that are being transferred as part of the POET alliance, but also the art of research and scholarship.

\section{References}

Australian Institute of Health and Welfare. (2015). Literature review of the impact of early childhood education and care on learning and development: Working paper. Canberra: Author.

Brayboy, B., M, J., Gough, H. R., Leonard, B., Roehl II, R. F., \& Solyom, J. A. (2011). Reclaiming scholarship: Critical Indigenous research methodologies. In S. D. Lapan, M. T. Quartaroli, \& F. J. Riemer (Eds.), Qualitative research: An introduction to methods and designs (pp. 423-450). Hoboken, NJ: Wiley.

Bronfenbrenner, U. (1979). The ecology of human development: Experiments in nature and design. Cambridge, MA: Harvard University Press.

Bronfenbrenner, U., \& Morris, P. A. (2006). The bioecological model of human development. In W. Damon \& R. M. Lerner (Eds.), Handbook of child psychology, Vol. 1: Theoretical models of human development (6 $6^{\text {th }}$ ed., pp. $793-$ 828). New York: Wiley.

Brooker, L. (2002). Starting school: Young children learning cultures. Buckingham: Open University Press.

Brooker, L. (2008). Supporting transitions in the early years. Maidenhead, England: Open University Press McGrawHill.

Bulkeley, J., \& Fabian, H. (2006). Well-being and belonging during early educational transitions. International Journal of Transitions in Childhood, 2, 18-31.

Carr, M. (2001). Assessment in early childhood settings: Learning stories. London: Sage.

Davies. J. (2014). Pedagogies of educational transitions: Continuity and change as children start school in rural areas. Unpublished research proposal. Charles Sturt University.

Department of Education Employment and Workplace Relations (DEEWR). (2009). Belonging, being and becoming: The early years learning framework for Australia. Department of Education Employment and Workplace Relations. https://docs.education.gov.au/system/files/doc/other/belonging_being_and_becoming_the_early_years_learning_fram ework_for_australia.pdf. Accessed 26 February 2015.

Dockett, S., \& Perry, B. (2004). What makes a successful transition to school? Views of Australian parents and teachers. International Journal of Early Years Education, 12(3), 217-230.

Dockett, S., \& Perry, B. (2007). Starting school: Perceptions, expectations and experiences. Sydney: UNSW Press.

Dockett, S. \& Perry, B. (2009). Readiness for school: A relational construct. Australasian Journal of Early Childhood, 34(1), 20-26.

Dockett, S., \& Perry, B. (2014a). Continuity of learning: A resource to support effective transition to school and school age care. Canberra, ACT: Australian Government Department of Education.

Dockett, S., \& Perry, B. (2014b). Research to policy: Transition to School Position Statement. In B. Perry, S. Dockett, \& A. Petriwskyj, (Eds.), Transitions to school: International research, policy and practice (pp. 277-294). Dordrecht: Springer.

Dockett, S., Petriwskyj, A., Perry, B. (2014). Theorising transition: Shifts and tensions. In B. Perry, S. Dockett, \& A. Petriwskyj, (Eds.), Transitions to school: International research, policy and practice (pp.1-18). Dordrecht: Springer.

Dunlop, A-W. (2014). Thinking about transitions: One framework or many? Populating the theoretical model over time. In B. Perry, S. Dockett, \& A. Petriwskyj, (Eds.), Transitions to school: International research, policy and practice (pp. 31-46). Dordrecht: Springer.

Dunlop, A-W., \& Fabian, H. (2002). Conclusions. In H. Fabian \& A-W. Dunlop (Eds.), Transitions in the early years: Debating continuity and progression for children in early education (pp. 146-154). London: Routledge/Falmer.

Educational Transitions and Change (ETC) Research Group. (2011). Transition to school: Position statement. AlburyWodonga, Australia: Research Institute for Professional Practice, Learning and Education, Charles Sturt University. http://www.csu.edu.au/faculty/educat/edu/transitions/publications/Position-Statement.pdf. Accessed 9 August 2015. 
Einarsdóttir, J. (2007). Children's voices on the transition from preschool to primary school. In A-W. Dunlop \& H. Fabian, (Eds.), Informing transitions in the early years: Research, policy and practice (pp.74-91). Maidenhead, England: Open University

Einarsdóttir, J. (2014). Reading of media accounts of transition to school in Iceland. In B. Perry, S. Dockett, \& A. Petriwskyj (Eds.), Transitions to school: International research, policy and practice (pp. 21-30). Dordrecht: Springer.

Elder, G. H., Jr. (1996). Human lives in changing societies: Life course and developmental insights. In R. B. Cairns, G. H. Elder, Jr., \& E. J. Costello (Eds.), Developmental science (pp. 31 - 62). New York: Cambridge University Press.

Garpelin, A. (2011). Borderlands, bridges and rites of passage: Understanding children's learning journeys from preschool into school. Application. Swedish Research Council, VR: Västerås: Mälardalen University.

Garpelin, A. (2014). Transition to school: A rite of passage in life. In B. Perry, S. Dockett, \& A. Petriwskyj (Eds.), Transitions to school: International research, policy and practice (pp.117-128). Dordrecht: Springer.

Giroux, H. A. (2005). Border crossings ( $2^{\text {nd }}$ ed.) New York: Routledge.

Graue, E. (2006). The answer is readiness - Now what is the question? Early Education and Development, 17(1), 43-56.

Graue, E., \& Reineke, J. (2014). The relation of research on readiness to research/practice of transitions. In B. Perry, S. Dockett, \& A. Petriwskyj (Eds.), Transitions to school: International research, policy and practice (pp.159-173). Dordrecht: Springer.

Hartley, C., Rogers, P., Smith, J., Peters, S., Carr, M. (2012). Across the border: A community negotiates the transition from early childhood to primary school. Wellington, New Zealand: NZCER.

Huser, C., Dockett, S., \& Perry, B. (2015). Transition to school: Revisiting the bridge metaphor. European Early Childhood Education Research Journal. DOI: 10.1080/1350293X.2015.1102414

Learning and Teaching Scotland (2005). Let's talk about pedagogy. Edinburgh: Scottish Executive. http://www.educationscotland.gov.uk/images/talkpedagogy_tcm4-193218.pdf. Accessed 17 May 2016.

Margetts, K. (2014). Transition and adjustment to school. In B. Perry, S. Dockett, \& A. Petriwskyj (Eds.), Transitions to school: International research, policy and practice (pp.75-87). Dordrecht: Springer.

Nakata, M. (2007). Disciplining the savages: Savaging the disciplines. Canberra: Aboriginal Studies Press.

Organisation for Economic Co-operation and Development (OECD). (2012). Education today 2013: The OECD perspective. Paris: OECD Publishing.

Perry, B., MacDonald, A., Gervasoni, A. (2015). Mathematics and transition to school: Theoretical frameworks and practical implications. In B. Perry, A. MacDonald, \& A. Gervasoni (Eds.), Mathematics and transition to school: International perspectives. Singapore: Springer Science \& Business Media.

Peters, S. (2004). "Crossing the border": An interpretive study of children making the transition to school. Unpublished $\mathrm{PhD}$ thesis. University of Waikato, New Zealand.

Peters, S. (2014). Chasms, bridges and borderlands: A transitions research 'across the border' from early childhood education to school in New Zealand. In B. Perry, S. Dockett, \& A. Petriwskyj (Eds.), Transitions to school: International research, policy and practice (pp.105-116). Dordrecht: Springer.

Pihama, L. (2010). Kaupapa Māori theory: Transforming theory in Aotearoa. He Pukenga Kōrero: A Journal of Māori Studies, 9(2), 5-14.

Siraj-Blatchford, I., Sylva, K., Muttock, S., Gilden, R., \& Bell, D. (2002). Researching effective pedagogy in the early years. London: Department for Education and Skills.

United Nations Children's Fund (UNICEF). (2012). The state of the world's children: Children in an urban world. New York: UNICEF.

van Gennep, A. (1960). The rites of passage. (trans: Minika, B.V. \& G.L. Caffee). London: Routledge and Kegan Paul.

Woodhead, M., \& Brooker, L. (2008). A sense of belonging. Early Childhood Matters, 111, 3-6.

Woodhead, M., \& Moss, P. (2007). Early childhood and primary education: Transitions in the lives of young children. Milton, Keynes, UK: The Open University. 